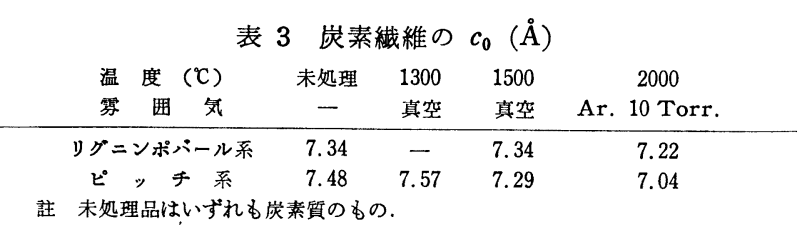

埋で，酸化性が著しく向上すること，酸化性の良いものは $c_{0}$ が $6.85 \AA$ 末満であることなどが明らかとなった。

一方, 表 3 は市販の炭素㵶維およびこれを表示の温度で一時間 熱処理した際の $c_{0}{ }^{12)}$ を示したものであるが，これで見ると $c_{0}$ の值は $2000^{\circ} \mathrm{C}$ で熱処理したものでも $7 \AA$ を越えて扣り，炭素 繊維の湿式酸化性は余り良くないものと推定される。

そこで，これらの繊維の表面に 1 で述べたような金属/酸素/炭 素の 3 元系よりなる中間層を設けようとする場合には，1）炭素 繊維にさらに熱処理を行って黒鉛化度を良くする。2）原料の配 合を変えて黒鉛化しやすい炭素繊維を作る，3）炭素瀻維の表面 に黒鉛化性の良い別の炭素層を被覆する，4）黑鉛化触媒 ${ }^{13)}$ を用 いるなどの方法を採用して，金属酸化物と酸化性のよい炭素とを 接触させておけば，所期の反応を一層容易に進め得るものと考兄

12）富塚 功, 田中劳雄, 渡辺 治, 未発表.

13）例之ば，石川忠夫，吉沢四郎，工化，96，929（1963）
られる。このうち 1）の場合は単に熱処理を行っただけでは出発 原料によっては，強さが低下したり，また纎維を巻いたまま熱処 理すると，そのくせが残ったりする場合があるので，いわゆる延 伸法を併用するのが得策であると思われる。しかしこの操作によ り価格が著しく上昇するのが欠点である。2）の場合，特にリグ ニンとポバールを原料とするものでは, リグニン ${ }^{14)}$ と若年炭占) で は, 化学構造上類似の点が多いので, ポバールを何かに代換すれ ば，黑鉛化しやすい炭素材は製造できるであろうが，紡系の点で 新たな問題が生じるかもしれない。また 3）の場合として，パイ ログラファイトを被覆する方法が挙げられる。被覆そのものは技 術的に問題はないが16), 被覆直後の $c_{0}$ は 6.85 内外なので ${ }^{17)}$, あるいは再熱処理が必要かもしれない。

14）例完ば, R.E.Kirk \& D.E. Othmer, “Encyclopedia of Chemical Technologie VIII”, Interscience, Encyclo. Pub. Inc., New York (1952), p. 329.

15）例艺ば, 本田英昌, “石岑化学工業”, 産業図書（1960）, p. 67 .

16）渡辺 治, 富塚 功, 生沢博夫, 宰業協会に投稿中 “炭素 繊維への熱分解黒鉛の被覆”。

17） O. Watanabe, I. Tomizuka, 案協誌, 77, 251 (1969).

\title{
衝撃圧搾ルチル粉体の $\mathrm{X}$ 線プロフィルの解析
}

(昭和 44 年 10 月 27 日受理)

\author{
斎藤進六・岩井津一・渡辺哲夫・䅄川日出貴*1
}

グリセリン液中爆発による粉体の衝撃圧縮実験法を述べ，ルチルの微細構造に及ぼす衝撃加工の効果を論じた。

衝撃加工されたルチル粉末のみかけ粒度を電子顕微鏡観察し，格子面 $\{110\}$ 亿垂直方向の結晶子の大きさ拉よび平均 2 乗平方

格歪を, Warren-Avervach の解析法により計算した。格子不整の熱処理による回復をるまた調べて, 次のような結果を得た。

1）みかけ粒度 $1 \mu$ 以下のルチル粉末を，衝撃圧縮すると，圧搾粉体が得られ，粉末粒子は破磁されない。

2）格子歪成分は，短距離では不均一であるようにみえるが，距離 $100 \AA$ にわたって平均されると，注定になり，その值

は，約 $0.4 \times 10^{-2}$ である。結晶子の大きさは，衝撃加工により加工前の約 $1000 \AA$ に対して約 $100 \AA$ に減少する。

3）衝撃加工により生じた格子不整は， $1000^{\circ} \mathrm{C} ， 1$ 時間の熱処理により除かれる。

\section{1 緒言}

近年, 爆発成形, 液中放電成形等の高速度エネルギー成形法の 研究が，数多く行なわれているが，七ラミック原材料のような脆 性固体に対しては, これらの研究1)は, 数少ないようにみえる。

一般に脆性固体の衝撃圧縮過程2)は，（1） 1 次的破砕，（2） 粉粒体としての 2 次的破砕，（3）破砕粒子のつき固めに分けら れるが，粉末粒子は，衝撃圧縮により，これ等に対応して，(a) みかけ粒度の減少，（b）粉末粒子の角がとれて微粒子が生成，

*1 Shinroku SaITo, Shinichi IWAI, Tetsuo Watanabe, Hideki MORIKAWA 東京工業大学工業材料研究所: 東京 都目黒区大岡山.

1) O.R.Bergmann, T.Barrington, J. Amer. Ceram. Soc., 49 [9], 502 (1966) ; R. W. Heckel, T. L. Youngblood, J. Amer. Ceram. Soc., 51 [7], 398 (1968).

2）久保輝一郎，水渡英二，中川有三，早川宗八郎，“粉体の 理論と応用”, 丸善 (1962) p. 13. （c）破砕粒子のつき固め等の加工を受けるであろう。他方粉末 粒子は, 単一な結晶子であるか, その集合体であるから, 衝撃加 工により結晶子が微細化したり，その格子歪が生ずる可能性が大 きい。

従来セラミック粉末を焼結する際の前加工として, 混合 ${ }^{3)}$, 静 水圧圧縮 ${ }^{4)}$ 等が行なわれ，これ等の加工が，焼結反応を促進した り, 均一化するのに有効であることが知られていて，これ等の効 果は, メカノケミカル効果と総称されている。

著者等は, 衝撃圧縮のセラミック原材料に及ぼすメカノケミカ ル効果に関する基礎的な知見を得る目的で，粒径 $1 \mu$ 以下のル チル粉体を, ゆるい充填状態から衝撃压縮して, 回収圧搾粉体の 形態, 格子不整の熱処理による回復, 結晶子の大きさ, 格子丕の

3）赤尾洋二, 野田悌一郎, 堤坂 覚, 渡辺哲夫, 第 41 回密 業協会総会講演要旨集 (1968-4) p. 8.

4）文藤進六, 渡辺哲夫, 岡田幸彦, 吉田忠文, 第 7 回案業基 礎討論会講演要旨集（1961-1) p. 84. 
大きさおよび分布を調べた。

$$
2 \text { 実 }
$$

\section{験}

\section{2・1 衝撃加工法}

ルチル粉末 (栃木化学製) を，約 $0.4 \mathrm{~g}$ 科取し，図 1 に示すよ らな，駆動装置の駆動鋼板(3)上の試料保持金具(6)（アルミニウム のリング $16 \mathrm{~mm} \phi \times 12.7 \mathrm{~mm} \phi \times 5$ $\mathrm{mm})$ 内に，ハンドプレスを使用し て圧入 $\left(500 \mathrm{~kg} / \mathrm{cm}^{2}\right)$ した。駆動板 を，シリンダー(2)下部に装備した 4 本のビス上に置き，固定板(1)および 放電爆圧容器(4)とシリンダーの接続 部は, ‘O’リングでシールした。容 器(4)内に圧力媒体としてグリセリン を満たし，シリンダー(2)内は，排気 孔(5)より回転真空ポンプにて，約 2 $\mathrm{mmHg}$ 程度に排気した。対向電極 (7)間のグリセリン液中放電爆压を利 用して，駆動鋼板を高速に加速し て，固定鋼板に衝突させて，試料を 衝撃圧縮した。駆動板の運動エネル ギーは, その平均速度を, シンクロ

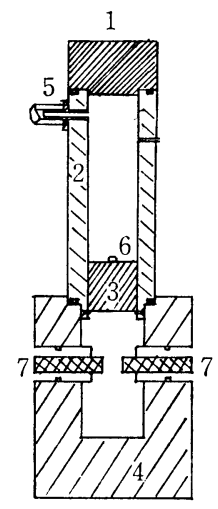

図 1 駆動装置の断面図 $1:$ 固定板, $2:$ シリンダー, 3 : 駆動板 (SNCM 8, $380 \mathrm{~g}, 40$ $\mathrm{mm} \phi \times 40 \mathrm{~mm}), 4$ : 爆圧容器, $5:$ 排気孔，6: 試料， $7:$ 対向電
スコープで計測して計算したが，約 $61(\mathrm{~kg} \cdot \mathrm{m})$ であった。固定 鋼板は，上方から垂力 10 ton を負荷することにより固定した。

\section{$2 \cdot 2$ 衝撃加工前後の粒子径の観察}

衝撃圧粉体の細片を, メノウ乳鉢で粉末にして, 蒸留水中に分 散させた試料扣よび原試料を, 同様にして, メッシュ上に採取し て, 電子顕微鏡（日立 HS 7 型）にて写真撮影した $(\times 5000)$ 。

\section{$2 \cdot 3$ 格子不整の $X$ 線測定}

Hall5) の式*5 $\beta \cos \theta / \lambda=1 / L+2 \xi \sin \theta / \lambda$ により, $\beta \cos \theta$ と $\sin \theta$ のプロットの最小 2 乗直線の傾きから, 衝撃圧搾ルチルの 格子不整度を求めた。

衝搾圧粉体の細片を, メノウ乳鉢で粉末にして, 衝撃加工試料 とした。これより無作為採取して得られる粉末を, それぞれ電気 炉中で $300^{\circ} \mathrm{C}, 600^{\circ} \mathrm{C}, 1000^{\circ} \mathrm{C} に 1$ 時間保持後放冷して, 熱処理 試料とした。常圧下の内部標準物質として，塩化ナトリウムを混 入した試料の回折線のプロフィルは, 理学電機のガイガーフレッ

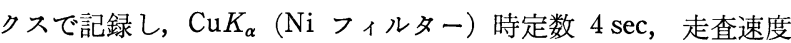
$0.25 / \mathrm{min}$ ，記録紙送り速度 $2 \mathrm{~cm} / \mathrm{min}$ で操作した。

\section{$2 \cdot 4$ 格子歪分布および結晶子の大きさの X 線測定}

衝撃加工前のルチルを，標準物質とした。標準物質および衝撃 加工試料の対応する回折線の組 $\{110\}-\{220\}$ のプロフィルは, Phillips 社の比例計数管 $(\mathrm{PW}-4025)$ を備えたX線回折計で記録 し, $\mathrm{Cu} K_{\alpha}\left(\mathrm{Ni}\right.$ フィルター), 走查速度 $0.25^{\circ} / \mathrm{min}$, 記録紙送り 速度 $2 \mathrm{~cm} / \mathrm{min}$ で操作した。このようにして得られたプロフィ ルを図 2 に示す。 Stokes ${ }^{7}$ ) の数值解析法により，衝撃加工試料の

5) W. H. Hall, Proc. Phys. Soc., A 62, 741 (1949).

6) W.R. Rachinger, J. Sci. Instrum., 25, 254 (1948).

*5 $\lambda$ は使用 X 線の波長 $[\AA], \theta$ は回折角度, $L$ は結晶子の大 きさ， $\xi$ は格子歪に比例する值， $\beta_{1}, \beta_{0}$ は Rachinger ${ }^{6)}$ の 方法により求められた試料拈よび $\mathrm{NaCl}$ の回折線の半価幅 とすると, $\beta=\sqrt{\beta_{1}{ }^{2}-\beta_{0}{ }^{2}}$.
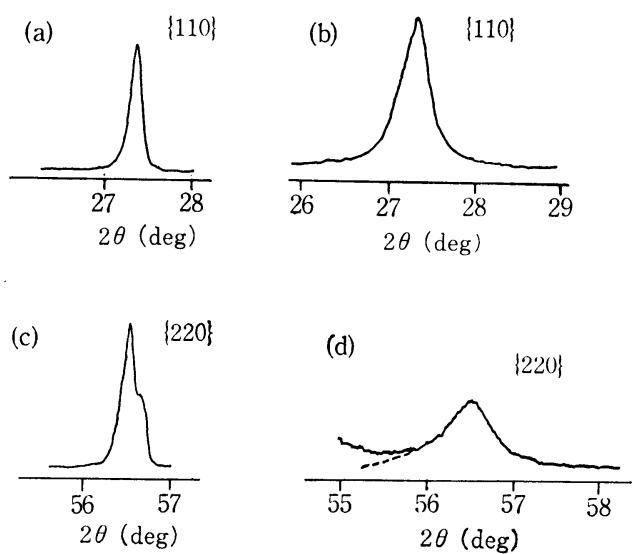

困 2 ルチルの衝撃前後の回折線のプロフィル

$$
\text { (a), (c): 衝撃前 (b), (d): 衝撃後 }
$$

プロフィル（b)，（d）から装置によるひろがり（a)，（c）を補 正し，その余弦変換 $A_{n}$ 扎よび正弦変換 $\mathrm{B}_{\mathrm{n}}$ を, FACOM-222 を利用して計算した。プロフィルが中心線に対してほぼ対称であ るので， $B_{n}$ は無視し得るほど小さい。

Warren-Avervach ${ }^{8)}$ の解析法によると，補正されたプロフィ ルの余弦変換 $A_{\mathrm{L}}$ から，結晶子の大きさ $D$ および平均 2 乗平方 根歪 $\left\langle\varepsilon_{\mathrm{L}}^{2}\right\rangle_{\mathrm{AV}}^{1 / 2}$ が，次式により計算される。

$$
A_{\mathrm{L}}=A_{\mathrm{L}}{ }^{\mathrm{P}} \cdot A_{\mathrm{L}}{ }^{\mathrm{D}}(l)
$$

$A_{\mathrm{L}}$ は, $L=n a_{3}$ ( $n$ は $A_{\mathrm{n}}$ の 調和数) として $A_{\mathrm{n}}$ より求めら れ, $A_{\mathrm{L}}{ }^{\mathrm{P}}$ は次式で与えられる。

$$
A_{\mathrm{L}}{ }^{\mathrm{P}}=1-\frac{L}{D}
$$

$A_{\mathrm{L}}{ }^{\mathrm{P}}(l)$ は, $[00 l]$ 方向の長さ $L$ 単位胞の重心の変位. $\Delta L$ が Gauss 分布をするときには，次式で与えられる。

$$
A_{\mathrm{L}}{ }^{\mathrm{D}}(l)=\left\langle\cos 2 \pi l_{0} L \varepsilon_{\mathrm{L}} / a\right\rangle_{\mathrm{AV}} \cdot \simeq \exp \left(-2 \pi^{2} l_{0}{ }^{2} L^{2}\left\langle\varepsilon_{\mathrm{L}}{ }^{2}\right\rangle_{\mathrm{AV}} \cdot / a^{2}\right.
$$

但し, $a$ は格子定数, $d_{h k l}$ は面間隔であり, $\varepsilon_{\mathrm{L}}=\Delta L / L, a / l_{0}=$ $d_{h k l}$ の関係があり, $a_{3}$ は次式で計算される。

$$
\frac{2 a_{3}}{\lambda}\left(\sin \theta_{\mathrm{M}}-\sin \theta_{0}\right)=\frac{1}{2}
$$

ここに $\lambda$ は使用 X 線の波長 $\left[\AA ̊ 0 ， \theta_{0}\right.$ はプロフィルのピーク 位置の回折角度, $\theta_{\mathrm{M}}$ はプロフィルがバックグラウンドに入る位 置の回折角度である。（1）,（2），（3）式より $\ln A_{\mathrm{L}}=\ln A_{\mathrm{L}}{ }^{\mathrm{P}}$ $-2 \pi^{2} l_{0}^{2}\left\langle\varepsilon_{\mathrm{L}}^{2}\right\rangle_{\mathrm{AV}} / a^{2}$ であるから, $\ln A_{\mathrm{L}}$ と $l_{0}^{2}$ のプロットの直線 の傾きから $\left\langle\varepsilon_{\mathrm{L}}{ }^{2}\right\rangle_{\mathrm{AV}}^{1 / 2}$ を計算し, 直線と $\ln A_{\mathrm{L}}$ 軸との切片から $A_{\mathrm{L}}{ }^{\mathrm{P}}$ を求め, $A_{\mathrm{L}}{ }^{\mathrm{P}}$ の $L=0$ に打ける接線と $L$ 軸との交点から $D$ を求めた。

\section{3 結果および考察}

\section{$3 \cdot 1$ 粉末粒子形態}

電子顕微鏡写真 1 より， 加工前のルチルのみかけ粒度は， $1 \mu$ 以下であり, 写真 2 より, 加工後のみかけ粒度が減少していると は観えない。加工後の粉末粒子の電顕像は, 加工前と比較して破 片状粒子の表面が不明瞭になっているのは, 衝撃加工により, 粒

7) A. R. Stokes, Proc. Phys. Soc. (London), 61, 382 (1948).

8) B.E. Warren, B. L. Averbach, J. Appl. Phys., 21 [7], 595 (1960) ; B. E. Warren, Acta. Crystallogr, 8, 483 (1955). 


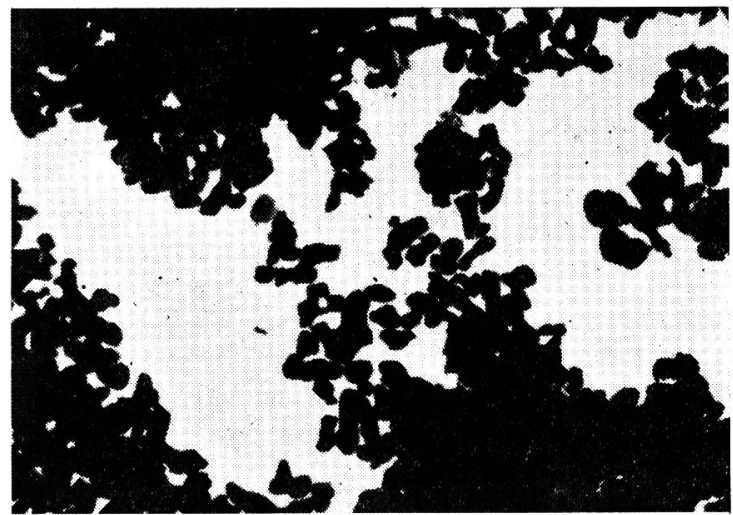

写真 1 ルチルの衝撃前の電子顕微鏡写真 $(\times 5000)$

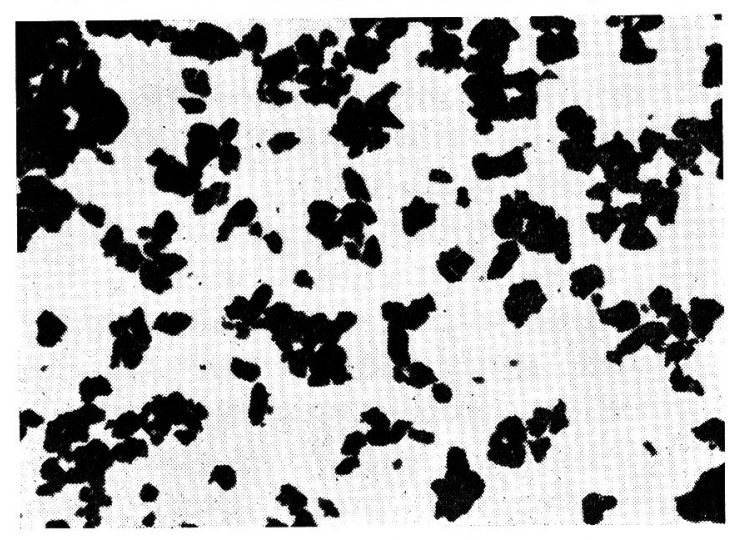

写真 2 ルチルの衝撃後の電子影微鏡写真 $(\times 5000)$

子の角がとれて微粒子が生成し，それが粘㘳面に付着しているた めであろう。

\section{$3 \cdot 2$ 格子不整の発生と熱処理回復}

衝撃加工試料の以折線のプロフィルは, 薯しい広がりと強菨 の低下のために, $2 \theta=27 \sim 60^{\circ}$ 間の 3 本の回折線 $\{101\},\{111\}$, $\{211\}$ のみが測定可能であった。これ等の回折線について $\beta \cos \theta$ 々 $\sin \theta$ とのプロットを図 3 亿示す。同図より Hall の式の $L を$ 評価することは困難であるが，最小 2 乘直線の傾きを $2 \xi$ とし て，これを格子不整度とする。格子不整度を熱処理温度に対して プロットすると図4のようになり，衝撃加工により生じた格子不

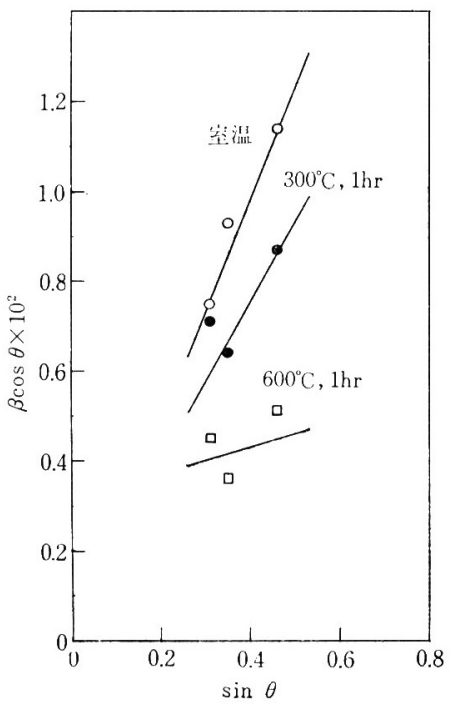

図 $3 \beta \cos \theta$ と $\sin \theta$ のプロット

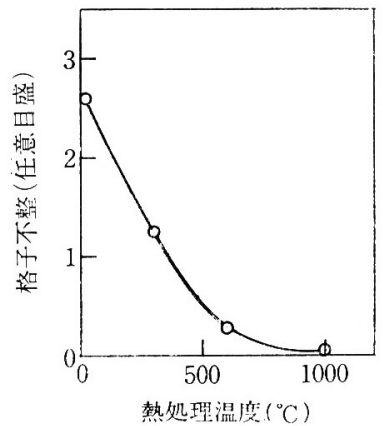

为 4 格子不整の熱処理儿上る问得

整は， $1000^{\circ} \mathrm{C} １$ 湔間の熱処理により除かれることが知られる。

回折線の回折牦度は，内部標準物質の回折们度に刘して相刘的 に求められ， $\Lambda$ STM Card から知られる值と $\pm 0.03^{\circ}$ の测定陨

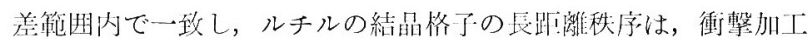
により破墩されないことが知られる。

\section{$3 \cdot 3$ 格子歪の大きさおよび分布}

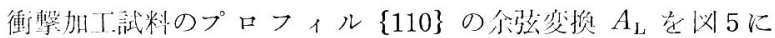

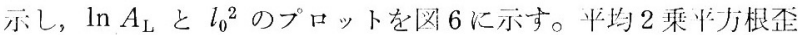
$\left\langle\varepsilon_{\mathrm{L}}{ }^{2}\right\rangle_{\mathrm{AV}}^{1 / 2}$ 类, [110] 力何の距離 $L$ に刘してプロットすると, 図 7 のよらになる。 $\left\langle\varepsilon_{\mathrm{L}}^{2}\right\rangle_{\mathrm{AV}}^{1 / 2} か ゙, L<100 \AA$ に预いてLの增大につれ て诚少していることは，格了歪成分 $\varepsilon_{\mathrm{L}}$ のばらつきが，Lの增大 につれて減少していることに相当し，篮距離の $\varepsilon_{\mathrm{L}}$ は，辰距離の

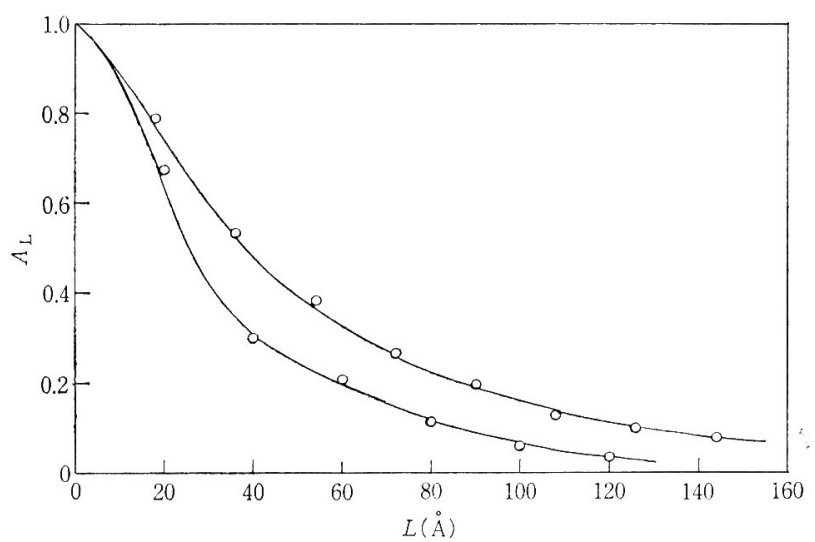

図 5 衝撃加工されたルチルの回折線の余弦変換 $A_{\mathrm{L}}$ は，装罳によるひろがりを補正さ扎 $L=n a_{3}$ と刘してブロットされている。

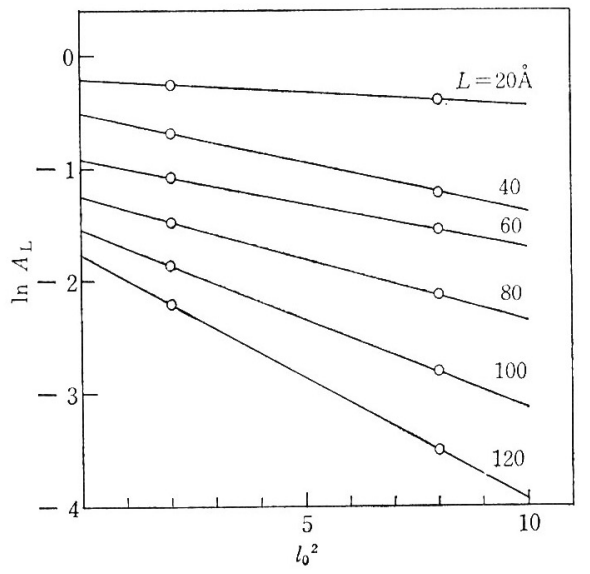

困 6 衝揧加工されたルチルの $\ln A_{\mathrm{L}}$ と $l_{0}^{2}$ のプロット 


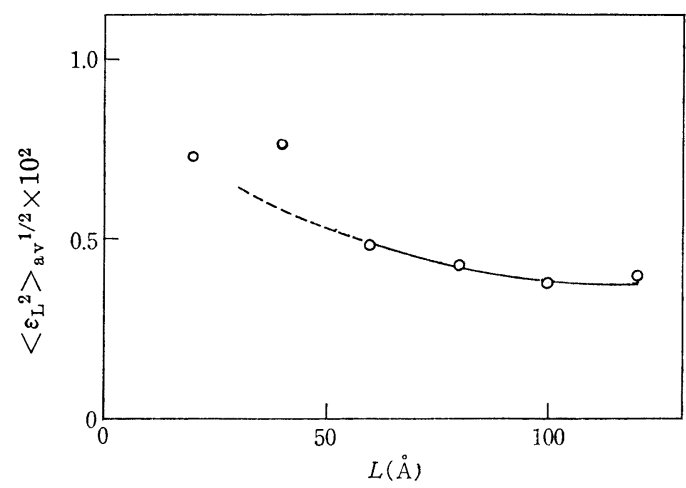

図 7 衝撃加工されたルチルの [110］の平均距離の 函数としての平均 2 乗平方根丕

$\varepsilon_{\mathrm{L}}$ と比較して，より不均一であることを示していると考えられ

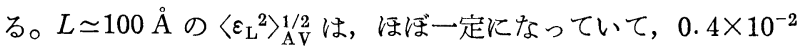
であることが知られる。

衝撃加工による結晶子粒界の転位のブロック化，バルクの転位 密度の増大等が，上記の解析結果の因子となっていると考えられ る。

\section{4 衝撃加工による結晶子の微細化}

結晶子の大きさの係数 $A_{\mathrm{L}}{ }^{\mathrm{P}}$ の [110] 方向の距離 $L$ に対するプ ロットを図 8 に示す。同図より，[110］方向の結晶子の大きさ

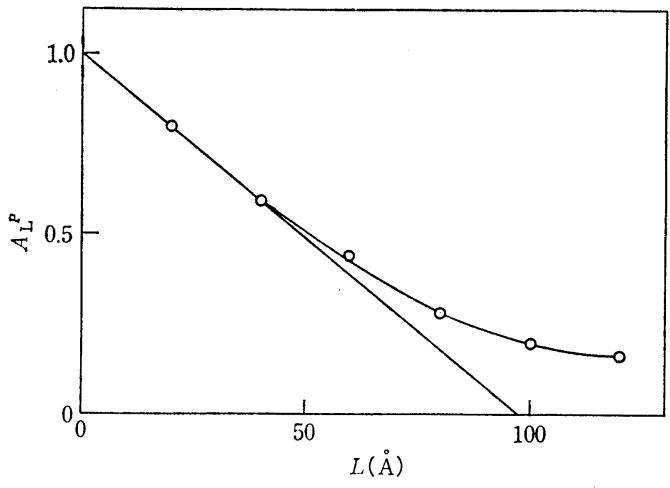

図 8 衝撃加工されたルチルの [110] の平均距離の 函数としての結晶子の大きさの係数

$D_{110}$ は, 約 $100 \AA$ であることが知られる。衝撃加工前の $D_{110}$ は, 半価幅の測定から, 約 $1000 \AA$ と計算されるので, 加工前後 の $D_{110}$ の減少比は, 約 $1 / 10$ である。

衝撃加工によるみかけ粒度の減少をともなわない結晶子の破砕 が，上記の解析結果の因子となっていると考えられる。

終りに，駆動装置作成にあたり扎世話になった東工大斎藤研究 室の岡田幸彦氏，および電子顕微鏡写真撮影をてつだっていただ いた東工大電子顕微鏡室の大木六郎氏に感謝いたします。 